\title{
Sid New Disease Reports \\ First report of papaya anthracnose caused by Colletotrichum fructicola in India
}

T.J. Saini ${ }^{1,2} *$ S.G. Gupta ${ }^{2}$ and R. Anandalakshmi ${ }^{1}$

${ }^{1}$ Mahyco Research Centre, Dawalwadi, Jalna-431203, Maharashtra, India; ${ }^{2}$ Government Institute of Forensic Science, Dr. Babasaheb Ambedkar Marathwada University, Aurangabad-431004, Maharashtra, India

*E-mail: teju.saini@gmail.com

Received: 07 Nov 2016. Published: 07 Dec 2016. Keywords: Carica papaya

Papaya (Carica papaya) is an important fruit crop grown in tropical and subtropical regions of India. India ranks first in papaya production in the world with over 5.54 million tonnes produced annually (FAOSTAT, 2013). In August 2016, a papaya fruit showing typical anthracnose symptoms of small, sunken, dark brown lesions was purchased from a market (Fig. 1) The fruit originated from a farmer's field in Karmad village, Aurangabad Maharashtra, India, and had been harvested before disease symptoms were visible on the fruit or host plant. Symptomatic fruit were incubated to allow development of disease symptoms. In India, Colletotrichum gloeosporioides is reported as the causal agent of papaya anthracnose (Tasiwal, 2008). However, C. gloeosporioides has recently been characterised as a species complex consisting of different species (Weir et al., 2012). Since Colletotrichum spp. are important pathogens worldwide on papaya and other fruits, it is important to identify and clarify the species on papaya in India.

Small pieces of necrotic tissue of papaya were examined under a microscope and spores were transferred onto potato dextrose agar (PDA) containing $50 \mathrm{mg} / \mathrm{l}$ streptomycin sulphate. The plates were incubated at $28^{\circ} \mathrm{C}$ for five to seven days. A pure culture of the Colletotrichum sp. isolate was obtained by sub-culturing onto fresh PDA plates. Identification of the isolate was based on morphological as well as molecular characterisation. Colonies on PDA had white aerial mycelia with an orange conidial mass (Fig. 2). The colour of the colony on the reverse side was light orange. The mycelial growth rate on the PDA plate at $28^{\circ} \mathrm{C}$ with a $16 \mathrm{~h}$ photoperiod was $15 \mathrm{~mm}$ per day. Conidia were single celled, cylindrical with rounded base and apex. Mean length and width of conidia was $15.3 \pm 1.5 \mu \mathrm{m}$ and $5.3 \pm 0.1$ $\mu \mathrm{m}$, respectively (Fig. 3).

PCR amplification of ITS rDNA and the partial $\beta$-tubulin gene was done using the universal primer pair ITS $4 / 5$ and $\beta$-tubulin gene $\mathrm{Bt} 2 \mathrm{a} / \mathrm{b}$ primers for molecular characterisation of the isolated Colletotrichum sp. Both sequences were deposited in GenBank (Accession Nos. KY007499and KY007500, respectively) and aligned with published sequences using MEGA version 6.0 (Tamura et al., 2013; Fig. 4). Blast searches in the NCBI database revealed that ITS and $\beta$-tubulin gene sequences had 99 and $100 \%$ identity with $C$. fructicola (KU366691 and KU552337, respectively). Although the ITS and $\beta$-tubulin gene sequences also showed high similarity with $C$. ignotum, $C$. siamense and $C$. gloeosporioides, the isolate obtained from infected papaya fruit was identified as $C$. fructicola based upon these phylogenetic analyses and morphological characteristics (Weir et al., 2012).

To confirm pathogenicity, papaya leaves and chilli fruits were wounded with a sterile syringe and inoculated with $10 \mu \mathrm{l}$ of a conidial suspension (ca. $10^{5}$ conidia/ml). Sterile water was used as a control. Inoculated papaya leaves and chilli fruits were kept in a chamber at $28^{\circ} \mathrm{C}$ with $90 \%$ humidity. After seven days typical anthracnose symptoms were observed on the papaya leaves as well as on chilli fruits (Fig. 5). No symptoms were observed on the controls. Colletotrichum fructicola was re-isolated from symptomatic papaya, thereby fulfilling Koch's postulates.

Colletotrichum fructicola has been reported in India as a causal agent of chilli anthracnose (Sharma \& Shenoy, 2014) and on papaya in Laos and Thailand (Phoulivong et al., 2012). To our knowledge, this is the first report of papaya anthracnose caused by $C$. fructicola in India.

\section{References}

FAOSTAT (2013). FAOSTAT data collection

[http://www.fao.org/faostat/en/\#data/QC]

Phoulivong S, McKenzie EHC, Hyde KD, 2012. Cross infection of Colletotrichum species; a case study with tropical fruits. Current Research in Environmental \& Applied Mycology 2, 99-111.

http://dx.doi.org/10.5943/cream/2/2/2

Sharma G, Shenoy BD, 2014. Colletotrichum fructicola and C. siamense are involved in chilli anthracnose in India. Archives of Phytopathology and Plant Protection 47, 1179-1194. http://dx.doi.org/10.1080/03235408.2013.833749

Tamura K, Stecher G, Peterson D, Filipski A, Kumar S, 2013. MEGA6: Molecular Evolutionary Genetics Analysis version 6.0. Molecular Biology and Evolution 30, 2725-2729. http://dx.doi.org/10.1093/molbev/mst197

Tasiwal V, 2008. Studies on Anthracnose - A Postharvest Disease of Papaya. Dharwad, India: University of Agriculture Sciences, MSc thesis.

Weir BS, Johnston PR, Damm U, 2012. The Colletotrichum gloeosporioides species complex. Studies in Mycology 73, 115-180.

http://dx.doi.org/10.3114/sim0011

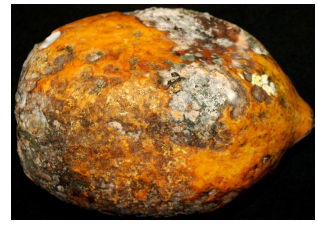

Figure 1

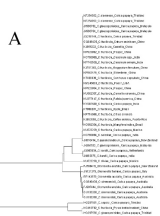

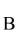

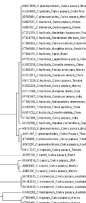

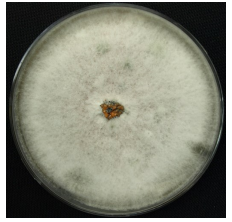

Figure 2

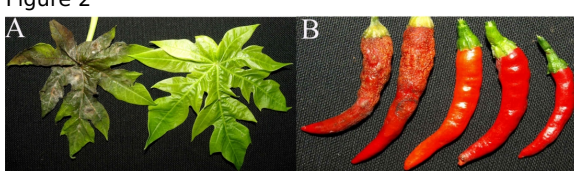

Figure 5

Figure 4

To cite this report: Saini TJ, Gupta SG, Anandalakshmi R, 2016. First report of papaya anthracnose caused by Colletotrichum fructicola in India. New Disease Reports 34, 27. http://dx.doi.org/10.5197/j.2044-0588.2016.034.027

(c) 2016 The Authors

This report was published on-line at www.ndrs.org.uk where high quality versions of the figures can be found. 